\title{
De novo synthesis of D- and L-fucosamine containing disaccharides
}

\author{
Daniele Leonori ${ }^{1}, \S$ and Peter H. Seeberger ${ }^{* 1,2}$
}

\section{Full Research Paper}

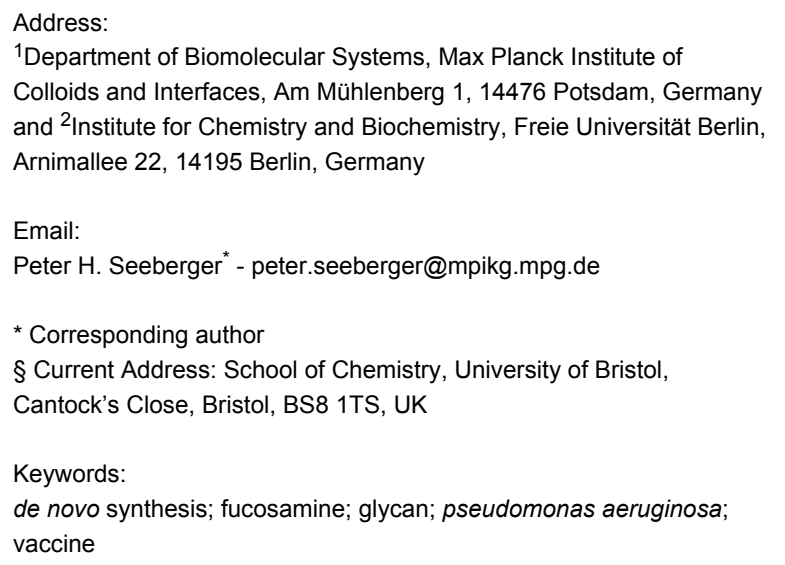

Beilstein J. Org. Chem. 2013, 9, 332-341. doi:10.3762/bjoc.9.38

Received: 14 October 2012

Accepted: 16 January 2013

Published: 14 February 2013

This article is part of the Thematic Series "Synthesis in the glycosciences II".

Guest Editor: T. K. Lindhorst

(C) 2013 Leonori and Seeberger; licensee Beilstein-Institut. License and terms: see end of document.

\begin{abstract}
The availability of rare monosaccharides that cannot be isolated from natural sources is currently limiting the access to the synthesis and the biological evaluation of complex bacterial cell-surface glycans. Here, we report the synthesis of D- and L-fucosamine building blocks by a de novo approach from L- and D-Garner aldehydes. These differentially protected monosaccharide building blocks were utilized to prepare disaccharides present on the surface of Pseudomonas aeruginosa bacteria.
\end{abstract}

\section{Introduction}

Protein functions are directly influenced by their glycosylation patterns $[1,2]$. Therefore, an understanding of protein glycosylation is of utmost importance in order to develop new therapeutics [3-6]. The ability of bacteria to colonize human hosts and cause diseases is directly influenced by their capacity to synthesize glycoproteins and express them on cell surfaces. This evidence makes it particularly relevant especially for the identification of novel antibacterial agents as well as vaccines [7-9] Those bacterial glycans often contain unusual monosaccharides that are not present in the human body. An immune response against these cell-surface glycans is the basis for the development of new vaccine candidates against bacterial infections [10$13]$.

Our efforts were directed to the development of new vaccine candidates [14-16] to prevent bacterial infections, including glycans of the highly pathogenic bacteria Pseudomonas aeruginosa. P. aeruginosa is a nosocomial pathogen that is involved in ventilator-associated pneumonia and has become resistant to many antimicrobials. The somatic pili of $P$. aeruginosa are a 
major virulence factor playing a pivotal role in the adherence and invasiveness of the bacterium. In 2001, the $P$. aeruginosa pilin $O$-linked glycans were found to be linear trisaccharides that are covalently attached to serine (Figure 1 ). The $O$-glycans contain a $\mathrm{D}$-fucosamine residue at the protein-binding site. This unusual monosaccharide is not present in eukaryotes, and therefore may be used to stimulate an antibacterial response in the host organism [17-23]. Access to differentially protected D- and L-fucosamine building blocks, which can be used in preparing the corresponding glycans, is instrumental for the evaluation of oligosaccharide-based vaccine candidates against this bacterium [24-28].

The synthesis of fucosamine building blocks has been reported in the literature, but it is highly affected by long synthetic sequences, extensive protecting group manipulations and expensive starting materials [29-33]. The de novo synthesis of rare sugars [34-43] provides an attractive alternative for rapid access to the required building blocks, but this approach has not been reported for D- or L-fucosamine [29-33,44-46].

Here, a full account of the de novo synthesis of differentially protected D- and L-fucosamine building blocks is described following a recent preliminary communication [47]. The building blocks prepared by de novo synthesis were used in the assembly of two disaccharides that are found on P. aeruginosa.

\section{Results and Discussion \\ De novo synthesis of D- and L-fucosamine building blocks}

Our retrosynthetic analysis of D-fucosamine envisioned the installation of the syn-1,2-diol unit by osmium-catalysed dihydroxylation of allylic ether A. It was anticipated that the conformation adopted by the molecule would allow for the formation of the required anti relationship between $C 3$ and $C 4$ hydroxy groups. A in turn would be accessed by the addition of
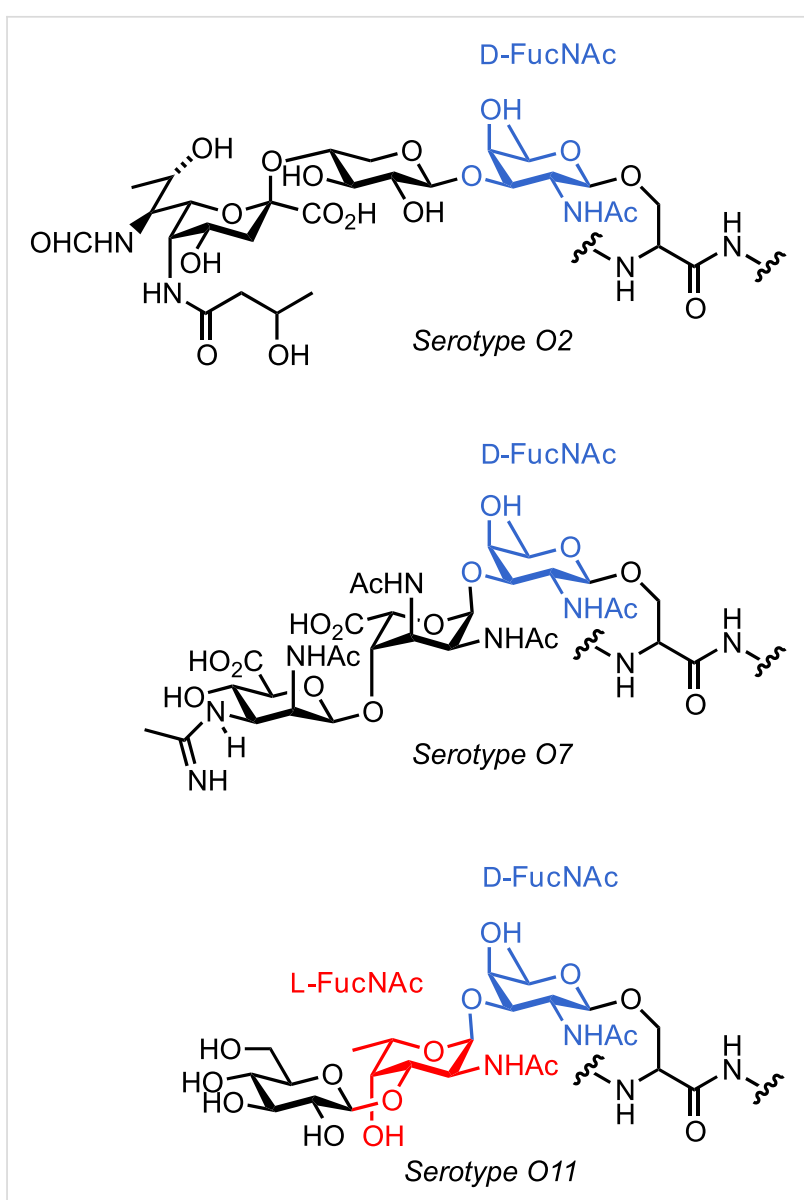

Figure 1: Structure of some O-linked glycans found on the cell surface of $P$. aeruginosa.

a carbon nucleophile to L-Garner aldehyde L-1 (Scheme 1) [48]. The fact that D- and L-Garner aldehydes are commercially available greatly facilitates the synthesis of both D- and L-fucosamine building blocks. The fucosamine residues are usually further elongated at the $C 3$ position in $P$. aeruginosa requiring two orthogonal protecting groups (PGs) at $C 3$ and $C 4$

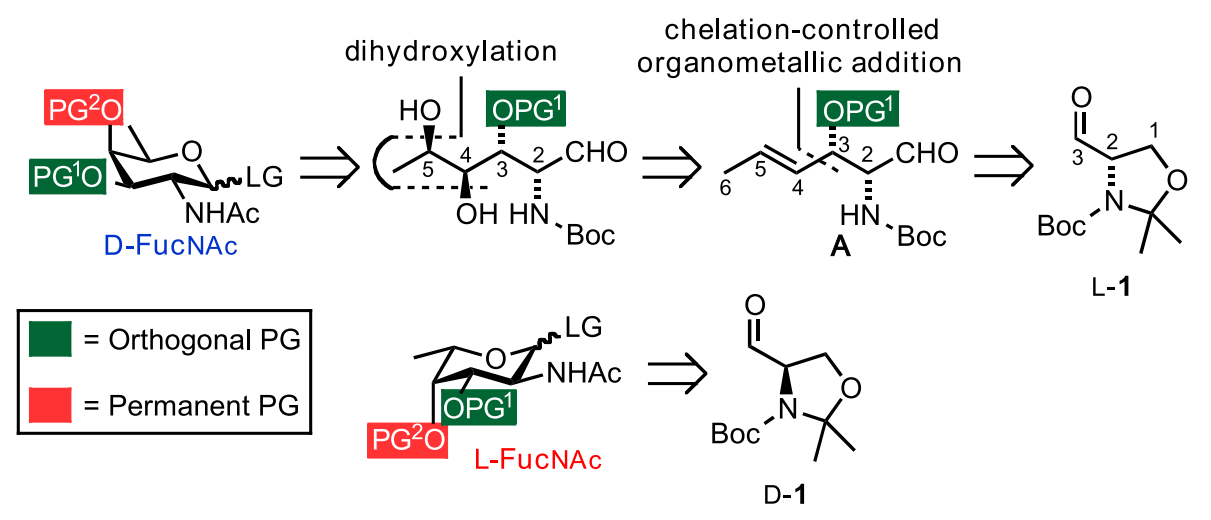

Scheme 1: Retrosynthetic analysis of D- and L-fucosamine building blocks. 
of the building block in order to differentiate the two hydroxy groups at a later stage.

The three carbon $C 4-C 6$ fragment of D-fucosamine was introduced by chelation-controlled addition $[49,50]$ of commercially available propynylmagnesium bromide to L-1 (Scheme 2A) $[51,52]$ The following $E$-selective alkyne reduction was accomplished by using diluted $\mathrm{RedAl}$ in $\mathrm{Et}_{2} \mathrm{O}$ [53]. This reaction proved to be highly dependent on the quality of the aluminium reagent obtained from commercial sources. Inspired by the work from the Trost group [54,55], an alternative reduction protocol based on a Ru-catalyzed hydrosilylation-protodesilylation sequence was pursued (Scheme 2B). Thus, exposure of alkyne 2 to $\mathrm{Cp} * \mathrm{Ru}\left(\mathrm{CH}_{3} \mathrm{CN}\right)_{3} \mathrm{PF}_{6}$ catalyst in the presence of the appropriate trialkylsilane gave the desired silylated products 7a-c (Table 1). The alkene geometry was confirmed as $Z$ by nuclear Overauser effect (nOe). Treatment of $\mathbf{7 a}-\mathbf{c}$ with TBAF and $\mathrm{CuI}$ delivered 3 in high yields. Generally, $\mathrm{BnMe}_{2} \mathrm{SiH}$ has been found to be optimal for these transformations [54,55]. In our hands however, the best results were achieved using the cheaper $\mathrm{Et}_{3} \mathrm{SiH}$ (Table 1). With a gram amount of $\mathbf{3}$ in hand, the C3 hydroxy group was protected and the acetonide removed by treatment with $p$-TSA. Oxidation of primary aminoalcohols 5a-b with the Dess-Martin reagent [56] yielded the desired aldehydes $\mathbf{6 a}-\mathbf{b}$, in five steps from commercially available starting materials. The two different $O$-protecting groups, namely naphthyl ether (Nap) [57-59] and benzoate ester (Bz), were introduced to gain access to two sets of electronically different and orthogonally protected derivatives (Scheme 2A).

\begin{tabular}{llll}
\hline \multicolumn{2}{l}{ Table 1: Hydrosilylation yields. } \\
\multicolumn{1}{l}{ entry } & $\mathrm{R}$ & yield (\%) \\
\hline 1 & $\mathbf{7 a :}$ & $\mathrm{Et}_{3}$ & 81 \\
2 & $\mathbf{7 b}:$ & $\mathrm{Et}_{2} \mathrm{Me}$ & 71 \\
3 & $\mathbf{7 c :}$ & $\mathrm{Me}_{2} \mathrm{Bn}$ & traces
\end{tabular}

Dihydroxylation of aldehyde 6a under standard Upjohn conditions gave, after peracetylation with $\mathrm{Ac}_{2} \mathrm{O}$, D-fucosamine building block D-8a in 81\% yield and 5:1 dr (anti/syn, diastereomers separable by column chromatography) (Scheme 3) [60-62]. The formation of the desired C3-C4-C5 syn,syn cyclic product was confirmed based on observation of a ${ }^{3} J_{H 3-H 4}$ coupling of $3.5 \mathrm{~Hz}$. When the same sequence of dihydroxylation-peracetylation was performed on Bz-substituted aldehyde $\mathbf{6 b}$, compound D-8b was formed in $71 \%$ as a single diastereomer (Scheme 3). This product was crystallized from $n$-hexane/EtOAc solvent mixture, and the stereochemical assignment was confirmed by X-ray analysis (data shown in Supporting Information File 1).
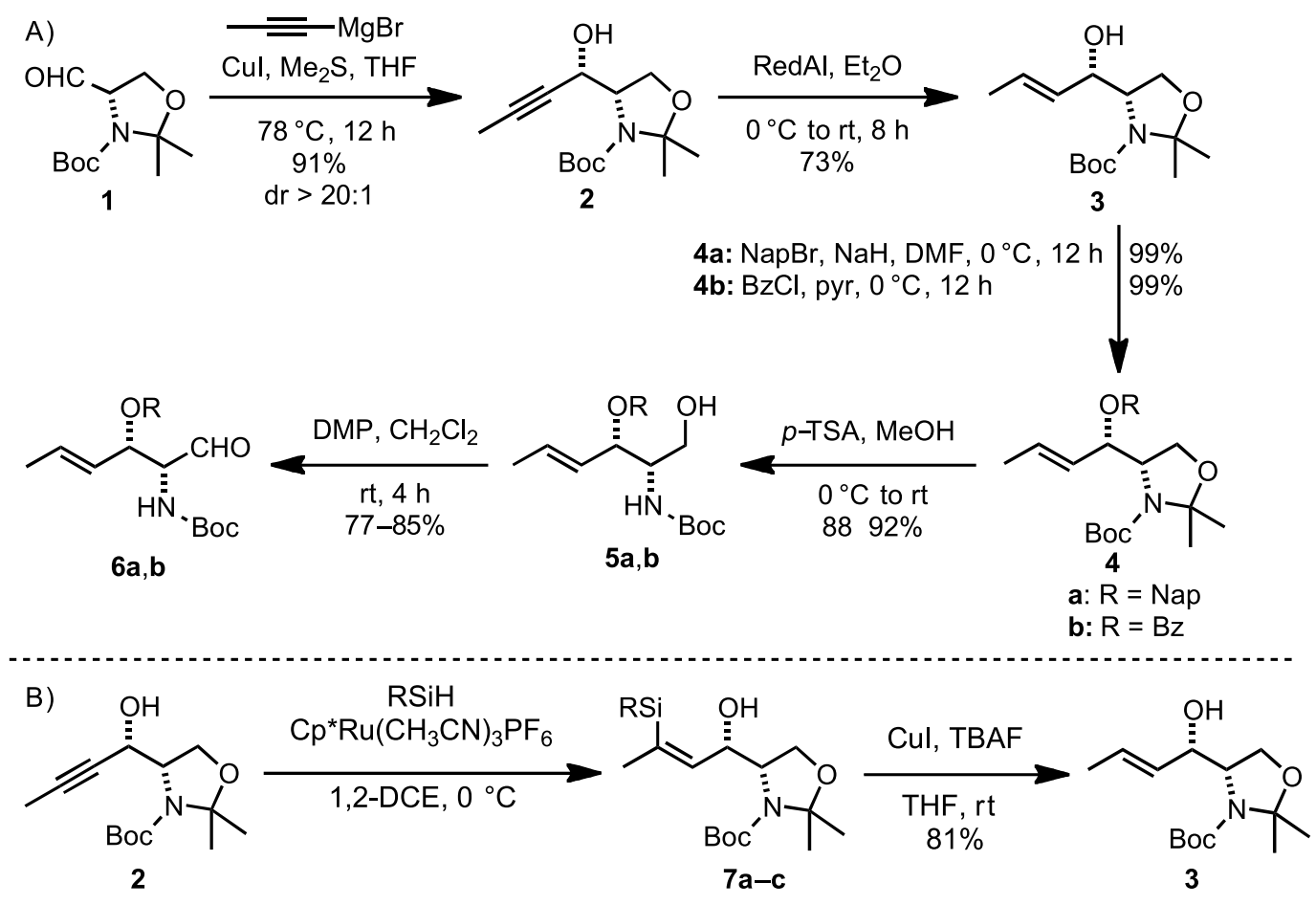

Scheme 2: (A) Synthesis of aldehydes $\mathbf{6 a}$ and $\mathbf{6 b}$. (B) Alkyne reduction by hydrosilylation-protodesilylation sequence (see Table 1). 


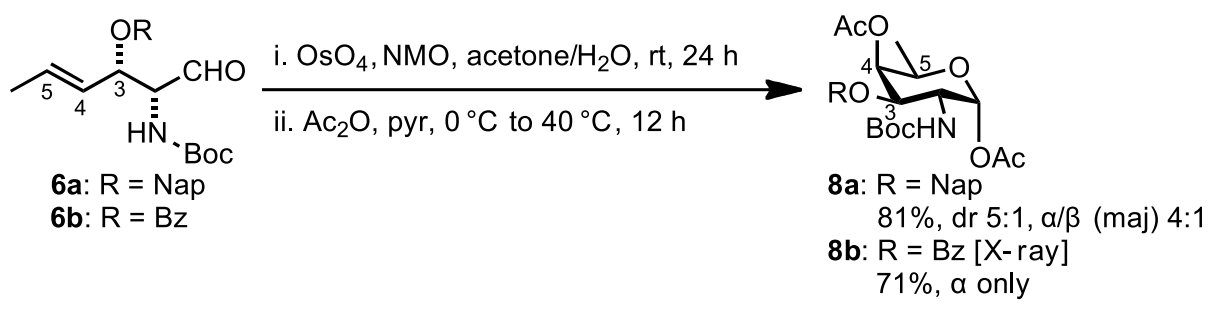

Scheme 3: Synthesis of D-fucosamine building blocks $\mathbf{8 a}$ and $\mathbf{8 b}$.

During the optimization of the synthetic sequence we explored potentially more economic oxidation protocols to convert the primary alcohol $\mathbf{5 a}$ to the D-fucosamine building block. Since $\alpha$-amino protected aldehydes easily undergo $\alpha$-epimerization, oxidation had to proceed under mild conditions in order to avoid the formation of the undesired D-talosamine building block D-9 (Scheme 4).

Several oxidation methods were tested (Table 2). All the reactions were performed sequentially without column-chromatographic purification of the aldehyde. Classic Swern oxidation [63] (Table 2, entry 2) gave a 2:1 mixture of $C 2$ epimers demonstrating the acid lability of aldehyde $\mathbf{6 a}$. This ratio in favour of the desired product was improved to $8: 1$ by switching the base from $\mathrm{Et}_{3} \mathrm{~N}$ to $\mathrm{iPr}_{2} \mathrm{EtN}$ as reported by Dondoni and co-workers (Table 2, entry 3) [64]. Parrikh-Doering oxidation [65] and TCCA-TEMPO mediated oxidation [66] (Table 2, entries 4 and 6, respectively) were not suitable as considerable amounts of D-talosamine building block were formed. DMP emerged as the reagent of choice for the oxidation of 5a. Interestingly, the dihydroxylation of aldehyde epi-6a resulted in the formation of talosamine D-9 as a single diastereomer while the dihydroxylation of 6a gave D-8a in 5:1 dr (Scheme 3).

Carrying out the synthetic sequence optimized for the synthesis of D-8a, on D-Garner aldehyde (D-1, commercially available)<smiles>C/C=C/[C@H](O[N+](=O)[O-])[C@@H](CO)[C@H](C)OC(=O)[O-]</smiles><smiles>CC(=O)OCC(=O)O[Na]</smiles>

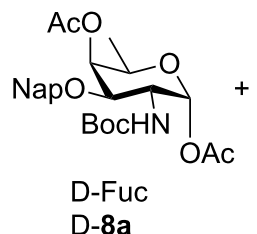

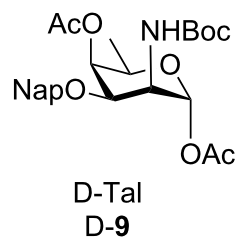

Scheme 4: Epimerization of aldehyde $6 \mathbf{a}$.

Table 2: Oxidation of 5 a to D-fucosamine D-8a

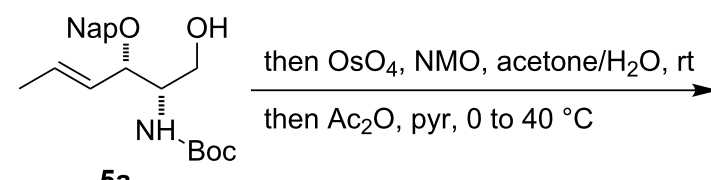

$5 a$

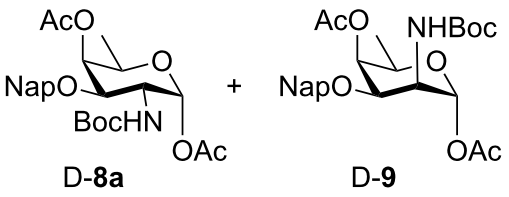

D-9

\begin{tabular}{lll}
\hline entry & reaction conditions & D-Fuc/D-Tal \\
\hline $1^{\mathrm{b}}$ & $\mathrm{DMP}, \mathrm{CH}_{2} \mathrm{Cl}_{2}, \mathrm{rt}$ then $1 \mathrm{M} \mathrm{Na}_{2} \mathrm{~S}_{2} \mathrm{O}_{3}$ in $\mathrm{NaHCO}_{3}$, sat. & $>20: 1$ \\
2 & $\mathrm{DMSO},(\mathrm{COCl})_{2}, \mathrm{Et}_{3} \mathrm{~N}, \mathrm{CH}_{2} \mathrm{Cl}_{2},-78{ }^{\circ} \mathrm{C}$ & $2: 1$ \\
3 & $\mathrm{DMSO},(\mathrm{COCl})_{2}, \mathrm{iPr}_{2} \mathrm{NEt}^{\mathrm{C}} \mathrm{CH}_{2} \mathrm{Cl}_{2},-78{ }^{\circ} \mathrm{C}$ & $8: 1$ \\
4 & $\mathrm{SO}_{3} \cdot \mathrm{pyr}, \mathrm{DMSO}, \mathrm{CH}_{2} \mathrm{Cl}_{2}, 0{ }^{\circ} \mathrm{C}$ & $2: 1$ \\
5 & $\mathrm{TCCA}, \mathrm{TEMPO}, \mathrm{CH}_{2} \mathrm{Cl}_{2}, 0^{\circ} \mathrm{C}$ & $3: 1$ \\
\hline
\end{tabular}

aDetermined by ${ }^{1} \mathrm{H}$ NMR analysis of the crude product after dihydroxylation and peracetylation. ${ }^{\mathrm{b}}$ Reaction run on $1 \mathrm{~g}$ scale. 
gave alcohol ent-5a (four steps, two chromatographic purifications) that after the direct oxidation-dihydroxylation-peracetylation protocol yielded the desired L-fucosamine building block L-8a (Scheme 5).

\section{Synthesis of fucosamine-containing disaccharides}

To facilitate the use of the bacterial monosaccharides in the glycan microarray platform and their conjugation to carrier proteins, an appropriate linker was required at the anomeric position [67]. Placement of a $C 3$ naphthyl ether anticipated the site for further glycosylation at this position, which typically serves as the connection to the next sugar. Therefore, building block $\mathbf{8 a}$ is ideal in terms of orthogonality and chemical synthesis. Hence, we tested the ability of D-8a to undergo anomeric functionalization and to effect glycosylation at the $C 3$ hydroxy group. Due to the presence of $N$-acetylated D- and L-fucosamine residues in $P$. aeruginosa $O$-linked glycans, the strategic $N$-protecting group was evaluated. Direct glycosylation by using the building block D-8a was not possible. Hence, a direct $N$-Boc deprotection $/ N$-acetylation sequence afforded D-10 in 84\% yield (Scheme 6A). Direct glycosylation of $\mathrm{D}-\mathbf{1 0}$ by using glycosylating agent $\mathbf{1 1}$ [67] and $\mathrm{BF}_{3} \cdot \mathrm{Et}_{2} \mathrm{O}$ as the activating agent, yielded the linker-functionalized monosaccharide D-12 as the $\beta$-anomer $\left({ }^{3} J_{H 1-H 2}=8.3 \mathrm{~Hz}\right.$, Scheme $\left.6 \mathrm{~A}\right)$. At this point, the $C 3$ naphthyl ether was cleaved under oxidative conditions and the corresponding alcohol was revealed by using a two-step deprotection protocol consisting of ester hydrolysis and hydrogenation. Monosaccharide D-13 was obtained in $85 \%$ yield (the $\beta$-linkage further confirmed by ${ }^{1} J_{C 1-H 1} 164.1 \mathrm{~Hz}$, Scheme 6A). Direct glycosylation after DDQ-deprotection was possible and the use of differentially protected glucose building block 15 [68] yielded the desired $\beta$-disaccharide 16 in $61 \%$ yield over two steps ( $\beta$ anomer, ${ }^{3} J_{H 1-H 2}$ of $7.8 \mathrm{~Hz}$, Scheme $\left.6 \mathrm{~A}\right)$. Global deprotection employed saponification, and hydrogenation gave the fully deprotected D-fucosamine containing disaccharide 17 (Scheme 6A).

When the same synthetic sequence was performed on L-FucNAc building block L-10 the fully deprotected monomer L-13 and disaccharide 19 were obtained in similar yields and selectivities (Scheme 6B). Diagnostic ${ }^{1} J_{C-H}$ analysis also corroborated the formation of the $\beta$-glycosydic linkages (Scheme 6B). Linker-terminated disaccharide 19 represents the terminal unit of the $P$. aeruginosa serotype $O 11 O$-linked glycan (Figure 1).

\section{Conclusion}

The de novo synthesis of differentially protected D- and L-fucosamine building blocks from D- and L-Garner aldehyde is reported. Placement of a naphthyl ether protecting group at the $C 3$ position allows for further elongation by glycosylation. The key oxidation step was optimized to minimize the formation of the unwanted D-talosamine building block D-9. The fucosamine building blocks prepared by de novo synthesis enabled the preparation of monosaccharides and disaccharides for attachment to microarray surfaces. The terminal disaccharide of $P$. aeruginosa $O 11 O$-linked glycan has been prepared and will be the basis for biological studies involving this pathogen.

\section{Experimental \\ General experimental details}

All reagents were obtained from commercial suppliers and were used without further purification unless otherwise specified. All reactions were conducted under an Ar atmosphere by using standard Schlenk techniques. THF and $\mathrm{Et}_{2} \mathrm{O}$ were distilled from purple $\mathrm{Na}$ /benzophenone diketyl; $\mathrm{CH}_{2} \mathrm{Cl}_{2}$, pyridine and $\mathrm{BF}_{3} \cdot \mathrm{Et}_{2} \mathrm{O}$ were distilled from $\mathrm{CaH}_{2}$. Deionized water was obtained from an in-house purification system. The compounds purified by flash chromatography were further concentrated by the removal of residual solvent under high vacuum ( $<0.2 \mathrm{mbar})$. ${ }^{1} \mathrm{H}$ NMR and ${ }^{13} \mathrm{C}$ NMR spectra were measured with a Varian 400-MR or Varian 600 spectrometer. The proton signal of residual, nondeuterated solvent $\left(\delta 7.26 \mathrm{ppm}\right.$ for $\mathrm{CHCl}_{3}$ or $\delta 4.79$ ppm for HDO) was used as an internal reference for ${ }^{1} \mathrm{H}$ spectra. For ${ }^{13} \mathrm{C}$ spectra, the chemical shifts are reported relative to the $\delta$ $77.36 \mathrm{ppm}$ resonance of $\mathrm{CDCl}_{3}$. Coupling constants ( $J$ values) are quoted to one decimal place with values in hertz $(\mathrm{Hz})$ and were corrected. Infrared (IR) spectra were recorded as thin films on a Perkin Elmer Spectrum 100 FTIR spectrophotometer. Optical rotations (OR) were measured with a Schmidt \& Haensch UniPol L 1000 spectrometer at a concentration (c) expressed in grams per hundred millilitres $(\mathrm{g} / 100 \mathrm{~mL})$. High-

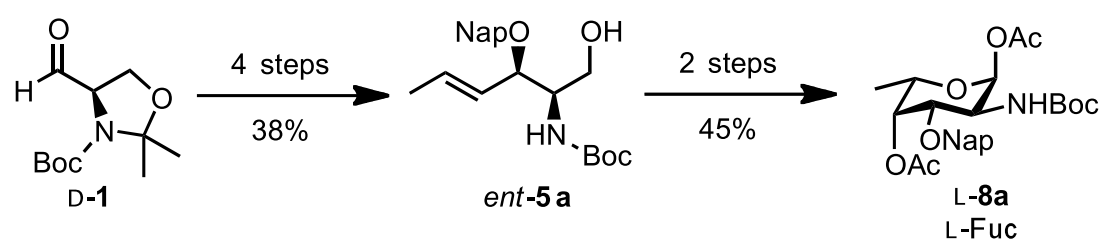


A)
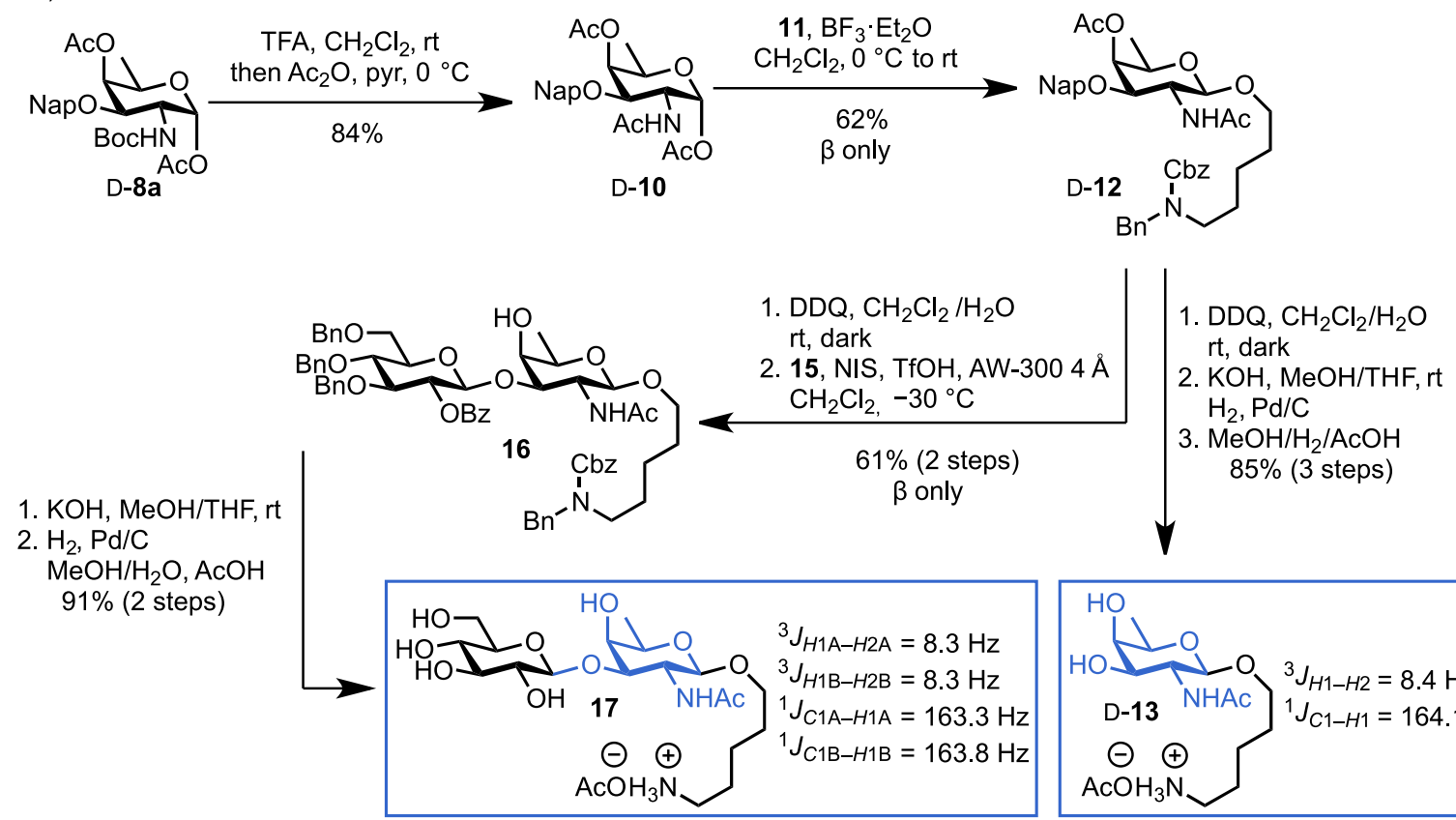

1. $\mathrm{KOH}, \mathrm{MeOH} / \mathrm{THF}, \mathrm{rt}$ $\mathrm{MeOH} / \mathrm{H}_{2} \mathrm{O}, \mathrm{AcOH}$ $91 \%$ (2 steps)

D-10

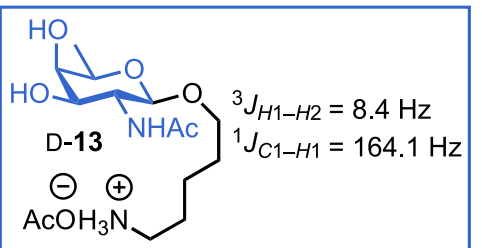

B)

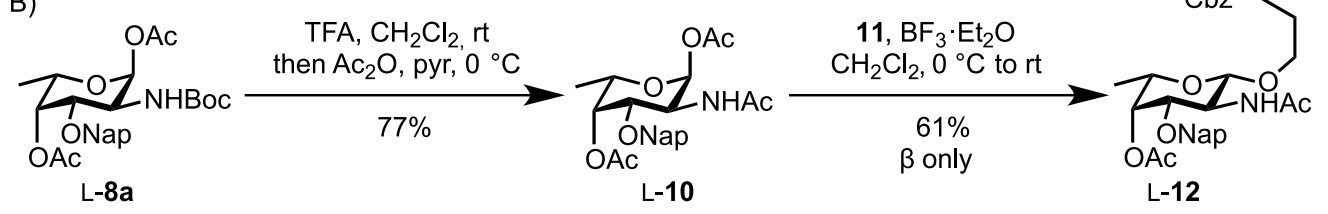

L-8a
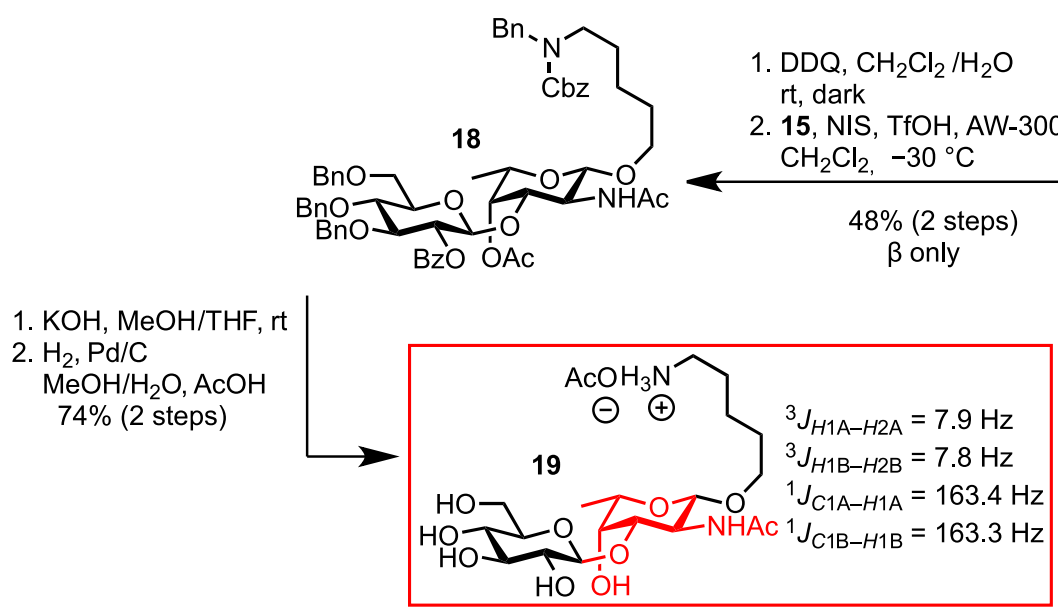
1. DDQ, $\mathrm{CH}_{2} \mathrm{Cl}_{2} / \mathrm{H}_{2} \mathrm{O}$ rt, dark
2. 15, NIS, TfOH, AW-300 $4 \AA$ $\mathrm{CH}_{2} \mathrm{Cl}_{2},-30^{\circ} \mathrm{C}$
$48 \%$ (2 steps) $\beta$ only

1. DDQ, $\mathrm{CH}_{2} \mathrm{Cl}_{2} / \mathrm{H}_{2} \mathrm{O}$ rt, dark

2. $\mathrm{KOH}, \mathrm{MeOH} / \mathrm{THF}$, rt $\mathrm{H}_{2}, \mathrm{Pd} / \mathrm{C}$

3. $\mathrm{MeOH} / \mathrm{H}_{2} / \mathrm{AcOH}$ $75 \%$ (3 steps)

1. $\mathrm{KOH}, \mathrm{MeOH} / \mathrm{THF}$, rt

$\mathrm{H}_{2}, \mathrm{Pd} / \mathrm{C}$

$\mathrm{MeOH} / \mathrm{H}_{2} \mathrm{O}, \mathrm{AcOH}$

$74 \%$ (2 steps)

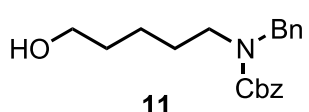

11

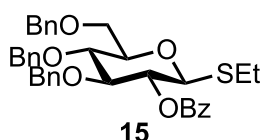

15 
resolution mass spectra (HRMS) were recorded with an Agilent 6210 ESI-TOF mass spectrometer at the Freie Universität Berlin, Mass Spectrometry Core Facility. Analytical thin-layer chromatography (TLC) was performed on Kieselgel $60 \mathrm{~F}_{254}$ glass plates precoated with a $0.25 \mathrm{~mm}$ thickness of silica gel. The TLC plates were visualized with UV light and by staining with Hanessian solution (ceric sulfate and ammonium molybdate in aqueous sulfuric acid) or potassium permanganate solution (potassium permanganate in basic aqueous solution). Column chromatography was performed by using Kieselgel 60 (230-400 mesh) silica gel with a typical 50-100:1 weight ratio of silica gel to crude product. For the preparation and characterization of compounds 2-10, D-12 and D-16 see [14].

\section{L-Fucosamine monosaccharide L-12}

Under the same reaction conditions reported in [14], L-10 (75 mg, $0.17 \mathrm{mmol}, 1.0$ equiv), 11 (86 mg, $0.26 \mathrm{mmol}$, 1.5 equiv) and $\mathrm{BF}_{3} \cdot \mathrm{Et}_{2} \mathrm{O}(33 \mathrm{~mL}, 0.26 \mathrm{mmol}, 1.5$ equiv) gave L-12 $(74 \mathrm{mg}, 61 \%)$ as an oil; $[\alpha]_{\mathrm{D}}{ }^{20}-63.2\left(c 2.0, \mathrm{CHCl}_{3}\right)$, other data as above.

\section{D-Fucosamine monosaccharide D-13}<smiles>[X]C([NH3+])CC(I)CCOC1O[C@H](C)[C@@H](O)[C@H](O)[C@H]1NC(C)=O</smiles>

A solution of D-12 (56 mg, $80.0 \mathrm{mmol}, 1.0$ equiv) in $\mathrm{CH}_{2} \mathrm{Cl}_{2}$ $(0.9 \mathrm{~mL})$ and $\mathrm{H}_{2} \mathrm{O}(90 \mathrm{~mL})$ was treated with DDQ $(21 \mathrm{mg}$, $94.0 \mathrm{mmol}, 1.2$ equiv) and stirred in the dark at $\mathrm{rt}$ for $2 \mathrm{~h}$. Saturated $\mathrm{NaHCO}_{3}(2 \mathrm{~mL})$ and $\mathrm{CH}_{2} \mathrm{Cl}_{2}(5 \mathrm{~mL})$ were added and the layers were separated. The aqueous layer was extracted with $\mathrm{CH}_{2} \mathrm{Cl}_{2}(2 \times 3 \mathrm{~mL})$. The combined organic layers were dried $\left(\mathrm{MgSO}_{4}\right)$, filtered and concentrated. The crude was purified by filtration over a short plug of silica gel eluting with $\mathrm{CH}_{2} \mathrm{Cl}_{2}$ / $\mathrm{MeOH}$ 9:1 (34 mg, 76\%) and immediately used for the next step. The monodeprotected compound $(18 \mathrm{mg}, 32.0 \mathrm{mmol}$, 1.0 equiv) in $\mathrm{MeOH}(0.4 \mathrm{~mL})$ and $\mathrm{THF}(0.4 \mathrm{~mL})$ was treated with $\mathrm{KOH}$ (1.8 mg, $32.0 \mathrm{mmol}, 1.0$ equiv) and stirred at $\mathrm{rt}$ for $30 \mathrm{~min} . \mathrm{H}_{2} \mathrm{O}(2 \mathrm{~mL})$ was added and the solvents were removed under vacuum. $\mathrm{CH}_{2} \mathrm{Cl}_{2}(5 \mathrm{~mL})$ was added and the layers were separated. The aqueous layer was extracted with $\mathrm{CH}_{2} \mathrm{Cl}_{2}$ $(2 \times 5 \mathrm{~mL})$. The combined organic layers were dried $\left(\mathrm{MgSO}_{4}\right)$, filtered and concentrated. The crude product was solubilised in $\mathrm{MeOH} / \mathrm{H}_{2} \mathrm{O} / \mathrm{AcOH}(2.0: 1.0: 0.05 \mathrm{~mL})$ and $\mathrm{Pd} / \mathrm{C}(10 \mathrm{mg})$ was added. The heterogeneous mixture was stirred under an atmosphere of $\mathrm{H}_{2}$ for $24 \mathrm{~h}$. The mixture was filtered over celite to give D-13 ( $8 \mathrm{mg}, 85 \%)$ as an amorphous solid; $[\alpha]_{\mathrm{D}}{ }^{20}+112.9(c$ $\left.1.1, \mathrm{H}_{2} \mathrm{O}\right) ;{ }^{1} \mathrm{H}$ NMR $\left(400 \mathrm{MHz}, \mathrm{D}_{2} \mathrm{O}\right) \delta 4.38(\mathrm{~d}, J=8.4 \mathrm{~Hz}, 1 \mathrm{H}$, $\left.\mathrm{CH}^{\mathrm{F}}\right), 3.83\left(\mathrm{dt}, J=10.1,6.3 \mathrm{~Hz}, 1 \mathrm{H}, \mathrm{CH}^{\mathrm{G}}\right), 3.79(\mathrm{dd}, J=10.7$, $\left.8.4 \mathrm{~Hz}, 1 \mathrm{H}, \mathrm{CH}^{\mathrm{E}}\right), 3.75-3.69\left(\mathrm{~m}, 2 \mathrm{H}, \mathrm{CH}^{\mathrm{C}}\right.$ and $\left.\mathrm{NH}\right), 3.68(\mathrm{dd}, J$ $\left.=10.7,3.4 \mathrm{~Hz}, 1 \mathrm{H}, \mathrm{CH}^{\mathrm{D}}\right), 3.66\left(\mathrm{dt}, J=10.1,6.3 \mathrm{~Hz}, 1 \mathrm{H}, \mathrm{CH}^{\mathrm{G}}\right)$, $3.41\left(\mathrm{q}, J=6.4 \mathrm{~Hz}, 1 \mathrm{H}, \mathrm{CH}^{\mathrm{B}}\right), 2.95\left(\mathrm{t}, J=7.6 \mathrm{~Hz}, 2 \mathrm{H}, \mathrm{CH}_{2}{ }^{\mathrm{K}}\right)$, $1.99\left(\mathrm{~s}, 3 \mathrm{H}, \mathrm{CH}_{3}\right), 1.87(\mathrm{AcOH}), 1.71-1.62\left(\mathrm{~m}, 2 \mathrm{H}, \mathrm{CH}_{2}{ }^{\mathrm{J}}\right)$, 1.59-1.51 (m, 2H, $\left.\mathrm{CH}_{2}{ }^{\mathrm{H}}\right), 1.39-1.29\left(\mathrm{~m}, 2 \mathrm{H}, \mathrm{CH}_{2}{ }^{\mathrm{I}}\right), 1.23(\mathrm{~d}, J$ $\left.=6.4 \mathrm{~Hz}, 3 \mathrm{H}, \mathrm{CH}_{3}{ }^{\mathrm{A}}\right) ;{ }^{13} \mathrm{C} \mathrm{NMR}\left(100 \mathrm{MHz}, \mathrm{D}_{2} \mathrm{O}\right) \delta 101.4$ $\left(\mathrm{CH}^{\mathrm{F}}\right), 71.0\left(\mathrm{CH}^{\mathrm{D}}\right), 70.4\left(\mathrm{CH}^{\mathrm{C}}\right), 70.3\left(\mathrm{CH}^{\mathrm{B}}\right), 69.8\left(\mathrm{CH}_{2}^{\mathrm{G}}\right), 52.0$ $\left(\mathrm{CH}^{\mathrm{E}}\right), 39.2\left(\mathrm{CH}_{2}{ }^{\mathrm{K}}\right), 28.0\left(\mathrm{CH}_{2}{ }^{\mathrm{J}}\right), 26.3\left(\mathrm{CH}_{2}{ }^{\mathrm{H}}\right), 23.1\left(\mathrm{CH}_{3}\right)$, $22.1\left(\mathrm{CH}_{3}\right), 21.9\left(\mathrm{CH}_{2}{ }^{\mathrm{I}}\right), 15.3\left(\mathrm{CH}_{3}{ }^{\mathrm{A}}\right)$; LRMS-ESI $(\mathrm{m} / \mathrm{z}): 291.2$ $\left[\mathrm{M}+\mathrm{H}^{+}\right]$; HRMS-ESI $(\mathrm{m} / \mathrm{z}):\left[\mathrm{M}+\mathrm{H}^{+}\right]$calcd for $\mathrm{C}_{13} \mathrm{H}_{27} \mathrm{~N}_{2} \mathrm{O}_{5}$, 291.1914; found, 291.1919.

\section{L-Fucosamine monosaccharide L-13}

Using the same reaction conditions reported for D-13, D-12 (24 mg, $34.0 \mathrm{mmol}, 1.0$ equiv), DDQ (21 mg, $41.0 \mathrm{mmol}$, 1.2 equiv), $\mathrm{KOH}$ (1.8 mg, $34.0 \mathrm{mmol}, 1.0$ equiv) and $\mathrm{Pd} / \mathrm{C}$ $(10 \mathrm{mg})$, gave L-13 (9 mg, 75\%) as an amorphous solid; $[\alpha]_{\mathrm{D}}{ }^{20}$ $-111.1\left(c 1.0, \mathrm{H}_{2} \mathrm{O}\right)$, other data as above.

\section{D-Fucosamine disaccharide 17}

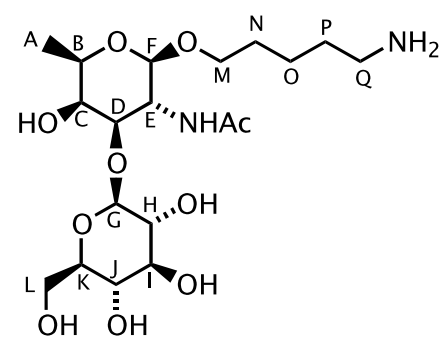

A solution of $16(21 \mathrm{mg}, 19.0 \mathrm{mmol}, 1.0$ equiv) in $\mathrm{MeOH}$ $(0.4 \mathrm{~mL})$ and THF $(0.4 \mathrm{~mL})$ was treated with $\mathrm{KOH}(1.0 \mathrm{mg}$, $19.0 \mathrm{mmol}, 1.0$ equiv) and stirred at $\mathrm{rt}$ for $30 \mathrm{~min} . \mathrm{H}_{2} \mathrm{O}(2 \mathrm{~mL})$ was added and the solvents were removed under vacuum. $\mathrm{CH}_{2} \mathrm{Cl}_{2}(5 \mathrm{~mL})$ was added and the layers were separated. The aqueous layer was extracted with $\mathrm{CH}_{2} \mathrm{Cl}_{2}(2 \times 5 \mathrm{~mL})$. The combined organic layers were dried $\left(\mathrm{MgSO}_{4}\right)$, filtered and concentrated. The crude product was solubilised in $\mathrm{MeOH} / \mathrm{H}_{2} \mathrm{O}$ / $\mathrm{AcOH}(2.0: 1.0: 0.05 \mathrm{~mL})$ and $\mathrm{Pd} / \mathrm{C}(20 \mathrm{mg})$ was added. The heterogeneous mixture was stirred under an atmosphere of $\mathrm{H}_{2}$ for $24 \mathrm{~h}$. The mixture was filtered over celite to give 17 (9 mg, $91 \%)$ as an amorphous solid; $[\alpha]_{\mathrm{D}}{ }^{20}+13.5\left(c 0.9, \mathrm{H}_{2} \mathrm{O}\right)$; ${ }^{1} \mathrm{H}$ NMR $\left(400 \mathrm{MHz}, \mathrm{D}_{2} \mathrm{O}\right) \delta 4.47\left(\mathrm{~d}, J=7.9 \mathrm{~Hz}, 1 \mathrm{H}, \mathrm{CH}^{\mathrm{G}}\right)$, $4.41\left(\mathrm{~d}, J=7.9 \mathrm{~Hz}, 1 \mathrm{H}, \mathrm{CH}^{\mathrm{F}}\right), 3.94\left(\mathrm{~d}, J=2.7 \mathrm{~Hz}, 1 \mathrm{H}, \mathrm{CH}^{\mathrm{C}}\right)$, $3.90\left(\mathrm{dd}, J=10.3,7.9 \mathrm{~Hz}, 1 \mathrm{H}, \mathrm{CH}^{\mathrm{E}}\right), 3.87-3.77\left(\mathrm{~m}, 3 \mathrm{H}, \mathrm{CH}^{\mathrm{L}} \&\right.$ $\left.\mathrm{CH}^{\mathrm{M}} \& \mathrm{CH}^{\mathrm{D}}\right), 3.70\left(\mathrm{q}, J=6.5 \mathrm{~Hz}, 1 \mathrm{H}, \mathrm{CH}^{\mathrm{B}}\right), 3.68(\mathrm{dd}, J=$ 12.1, 3.4 Hz, 1H, CH$\left.{ }^{\mathrm{L}}\right), 3.54\left(\mathrm{dt}, J=10.0,6.2 \mathrm{~Hz}, 1 \mathrm{H}, \mathrm{CH}^{\mathrm{M}}\right)$, 3.44-3.32 (m, 3H, $\mathrm{CH}^{\mathrm{I}}, \mathrm{CH}^{\mathrm{J}}$ and $\left.\mathrm{CH}^{\mathrm{K}}\right), 3.25(\mathrm{t}, J=7.9 \mathrm{~Hz}, 1 \mathrm{H}$, $\left.\mathrm{CH}^{\mathrm{H}}\right), 2.94\left(\mathrm{t}, J=7.6 \mathrm{~Hz}, 2 \mathrm{H}, \mathrm{CH}_{2} \mathrm{Q}\right), 1.97\left(\mathrm{~s}, 3 \mathrm{H}, \mathrm{CH}_{3}\right), 1.90$ (s, 3H, AcOH), 1.68-1.59 (m, 2H, $\left.\mathrm{CH}_{2}{ }^{\mathrm{P}}\right), 1.58-1.50(\mathrm{~m}, 2 \mathrm{H}$, $\left.\mathrm{CH}_{2}{ }^{\mathrm{N}}\right), 1.41-1.32\left(\mathrm{~m}, 2 \mathrm{H}, \mathrm{CH}_{2}{ }^{\mathrm{O}}\right), 1.22(\mathrm{~d}, J=6.5 \mathrm{~Hz}, 3 \mathrm{H}$, $\left.\mathrm{CH}_{3}{ }^{\mathrm{A}}\right) ;{ }^{13} \mathrm{C}$ NMR $\left(100 \mathrm{MHz}, \mathrm{D}_{2} \mathrm{O}\right) \delta 104.2\left(\mathrm{CH}^{\mathrm{G}}\right), 101.1$ 
$\left(\mathrm{CH}^{\mathrm{F}}\right), 80.2\left(\mathrm{CH}^{\mathrm{D}}\right), 75.5(\mathrm{CH}), 75.4(\mathrm{CH}), 72.7\left(\mathrm{CH}^{\mathrm{H}}\right), 70.4(2$ $\left.\times \mathrm{CH}^{\mathrm{B} \& \mathrm{C}}\right), 69.8\left(\mathrm{CH}_{2}^{\mathrm{L}}\right), 69.2(\mathrm{CH}), 60.3\left(\mathrm{CH}_{2}{ }^{\mathrm{M}}\right), 50.8\left(\mathrm{CH}^{\mathrm{E}}\right)$, $39.1\left(\mathrm{CH}_{2}{ }^{\mathrm{Q}}\right), 28.0\left(\mathrm{CH}_{2}{ }^{\mathrm{N}}\right), 26.2\left(\mathrm{CH}_{2}{ }^{\mathrm{P}}\right), 23.1\left(\mathrm{CH}_{3}\right), 22.1$ $\left(\mathrm{CH}_{3}\right), 22.0\left(\mathrm{CH}_{2}{ }^{\mathrm{O}}\right), 15.3\left(\mathrm{CH}_{3}{ }^{\mathrm{A}}\right)$; LRMS-ESI $(\mathrm{m} / \mathrm{z}): 453.2[\mathrm{M}$ $\left.+\mathrm{Na}^{+}\right]$; HRMS-ESI $(\mathrm{m} / \mathrm{z}):\left[\mathrm{M}+\mathrm{H}^{+}\right]$calcd for $\mathrm{C}_{19} \mathrm{H}_{37} \mathrm{~N}_{2} \mathrm{O}_{10}$, 453.2443; found, 453.2468 .

\section{L-Fucosamine disaccharide 18}

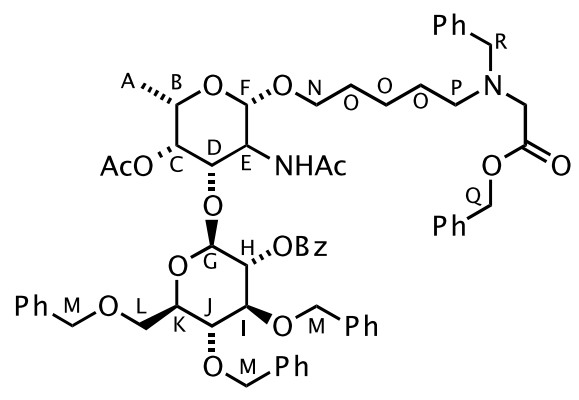

A solution of L-12 (60 mg, $86 \mathrm{mmol}, 1.0$ equiv) in $\mathrm{CH}_{2} \mathrm{Cl}_{2}$ $(1 \mathrm{~mL})$ and $\mathrm{H}_{2} \mathrm{O}(0.1 \mathrm{~mL})$ was treated with DDQ $(21 \mathrm{mg}$, $95 \mathrm{mmol}, 1.2$ equiv) and stirred in the dark at $\mathrm{rt}$ for $2 \mathrm{~h}$. Saturated $\mathrm{NaHCO}_{3}(2 \mathrm{~mL})$ and $\mathrm{CH}_{2} \mathrm{Cl}_{2}(5 \mathrm{~mL})$ were added and the layers were separated. The aqueous layer was extracted with $\mathrm{CH}_{2} \mathrm{Cl}_{2}(2 \times 3 \mathrm{~mL})$. The combined organic layers were dried $\left(\mathrm{MgSO}_{4}\right)$, filtered and concentrated. The crude was purified by filtration over a short plug of silica gel eluting with $\mathrm{CH}_{2} \mathrm{Cl}_{2}$ / $\mathrm{MeOH}(9: 1)$ and immediately used for the next step. An ovendried flask was immediately charged with the product and $\mathbf{1 5}$ (77 mg, $0.12 \mathrm{mmol}, 1.5$ equiv) was added. The flask was left under high vacuum for $4 \mathrm{~h}$. After refilling the flask with argon, freshly distilled $\mathrm{CH}_{2} \mathrm{Cl}_{2}(1.5 \mathrm{~mL})$ was added, and the mixture was cooled to $-30{ }^{\circ} \mathrm{C}$. NIS ( $29 \mathrm{mg}, 0.13 \mathrm{mmol}, 1.5$ equiv) and TfOH ( $4 \mathrm{~mL}, 43 \mathrm{mmol}, 0.5$ equiv) were added. The mixture was stirred at $-30{ }^{\circ} \mathrm{C}$ for $4 \mathrm{~h}$ and then it was allowed to warm to rt overnight. Saturated $\mathrm{Na}_{2} \mathrm{SO}_{3}(3 \mathrm{~mL})$ and $\mathrm{CH}_{2} \mathrm{Cl}_{2}(3 \mathrm{~mL})$ were added and the layers were separated. The aqueous layer was extracted with $\mathrm{CH}_{2} \mathrm{Cl}_{2}(2 \times 5 \mathrm{~mL})$. The combined organic layers were dried $\left(\mathrm{MgSO}_{4}\right)$, filtered and evaporated. Purification by column chromatography on silica gel, eluting with $n$-hexane/EtOAc (6:4), gave $\mathbf{1 8}(45 \mathrm{mg}, 48 \%)$ as an oil; $R_{\mathrm{f}} 0.22$ $\left[n\right.$-hexane/EtOAc (4:1)]; $[\alpha]_{\mathrm{D}}{ }^{20}-5.5\left(c 0.3, \mathrm{CHCl}_{3}\right)$; FTIR (film) $v_{\max }\left(\mathrm{cm}^{-1}\right): 3321,2925,2857,1743,1716,1705,1662$, 1368, 1271, 1240, 1071; ${ }^{1} \mathrm{H} \mathrm{NMR}\left(400 \mathrm{MHz}, \mathrm{CDCl}_{3}\right.$, rotamers) $\delta 8.04(\mathrm{~d}, 2 \mathrm{H}, J=7.3 \mathrm{~Hz}, 2 \times \mathrm{CH}), 7.57(\mathrm{tt}, J=7.4,1 \mathrm{H}, 1.2$ $\mathrm{CH}), 7.44(\mathrm{t}, J=7.7 \mathrm{~Hz}, 2 \mathrm{H}, 2 \times \mathrm{CH}), 7.35-7.22(\mathrm{~m}, 17 \mathrm{H}, 17 \times$ $\mathrm{CH}), 7.17-7.04(\mathrm{~m}, 8 \mathrm{H}, 8 \times \mathrm{CH}), 5.88(\mathrm{br} \mathrm{d}, J=6.5 \mathrm{~Hz}, 0.5 \mathrm{H}$, $\mathrm{NH}), 5.73$ (br d, $J=6.0 \mathrm{~Hz}, 0.5 \mathrm{H}, \mathrm{NH}), 5.21$ (dd, $J=9.1$, $\left.8.0 \mathrm{~Hz}, 1 \mathrm{H}, \mathrm{CH}^{\mathrm{H}}\right), 5.17$ (br s, $\left.1 \mathrm{H}, \mathrm{CH}^{\mathrm{Q}}\right), 5.14\left(\right.$ br s, $1 \mathrm{H}, \mathrm{CH}^{\mathrm{Q}}$ ), $5.13\left(\mathrm{~d}, J=3.5 \mathrm{~Hz}, 1 \mathrm{H}, \mathrm{CH}^{\mathrm{C}}\right), 5.07\left(\mathrm{~d}, J=8.0 \mathrm{~Hz}, 1 \mathrm{H}, \mathrm{CH}^{\mathrm{F}}\right)$, $4.79\left(\mathrm{~d}, J=10.8 \mathrm{~Hz}, 1 \mathrm{H}, \mathrm{CH}^{\mathrm{M}}\right), 4.70(\mathrm{~d}, J=11.0 \mathrm{~Hz}, 1 \mathrm{H}$, $\left.\mathrm{CH}^{\mathrm{M}}\right), 4.65-4.53\left(\mathrm{~m}, 6 \mathrm{H}, \mathrm{CH}^{\mathrm{D}} \& \mathrm{CH}^{\mathrm{G}} \& 4 \times \mathrm{CH}^{\mathrm{M}}\right), 4.52-4.46$ $\left(\mathrm{m}, 2 \mathrm{H}, \mathrm{CH}_{2}{ }^{\mathrm{R}}\right), 3.86\left(\mathrm{t}, J=9.3 \mathrm{~Hz}, 1 \mathrm{H}, \mathrm{CH}^{\mathrm{I}}\right), 3.82-3.74(\mathrm{~m}$, $\left.4 \mathrm{H}, \mathrm{CH}^{\mathrm{J}}, \mathrm{CH}_{2}{ }^{\mathrm{L}}, \mathrm{CH}^{\mathrm{N}}\right), 3.67\left(\mathrm{q}, J=6.4 \mathrm{~Hz}, 1 \mathrm{H}, \mathrm{CH}^{\mathrm{B}}\right), 3.50(\mathrm{br}$ $\left.\mathrm{dt}, J=9.6,2.3 \mathrm{~Hz}, 1 \mathrm{H}, \mathrm{CH}^{\mathrm{K}}\right), 3.44-3.40\left(\mathrm{~m}, 1 \mathrm{H}, \mathrm{CH}^{\mathrm{N}}\right)$, 3.23-3.17 (m, $3 \mathrm{H}, \mathrm{CH}^{\mathrm{E}}$ and $\left.\mathrm{CH}_{2}{ }^{\mathrm{P}}\right), 1.85$ and $1.81\left(\mathrm{~s}, 3 \mathrm{H}, \mathrm{CH}_{3}\right)$, $1.53-1.50\left(\mathrm{~m}, 3 \mathrm{H}, 3 \times \mathrm{CH}^{\mathrm{O}}\right), 1.45\left(\mathrm{~s}, 3 \mathrm{H}, \mathrm{CH}_{3}\right), 1.29-1.21(\mathrm{~m}$, $\left.3 \mathrm{H}, 3 \times \mathrm{CH}^{\mathrm{O}}\right), 1.08\left(\mathrm{~d}, J=6.4 \mathrm{~Hz}, 3 \mathrm{H}, \mathrm{CH}_{3}{ }^{\mathrm{A}}\right) ;{ }^{13} \mathrm{C} \mathrm{NMR}$ $\left(100 \mathrm{MHz}, \mathrm{CDCl}_{3}\right.$, rotamers) $\delta 171.2(\mathrm{C}=\mathrm{O}), 170.5(\mathrm{C}=\mathrm{O})$, $165.1(\mathrm{C}=\mathrm{O}), 137.9(2 \times \mathrm{C}), 137.7(2 \times \mathrm{C}), 137.6(\mathrm{C}), 133.2(2$ $\times \mathrm{CH}), 130.1(2 \times \mathrm{CH}), 129.5(\mathrm{C}), 128.5(2 \times \mathrm{CH}), 128.4(4 \times$ $\mathrm{CH}), 128.3(4 \times \mathrm{CH}), 128.2(4 \times \mathrm{CH}), 127.9(2 \times \mathrm{CH}), 127.8(4$ $\times \mathrm{CH}), 127.7(\mathrm{CH}), 127.6(\mathrm{CH}), 127.3(\mathrm{CH}), 127.2(\mathrm{CH}), 127.1$ $(\mathrm{CH}), 99.6(\mathrm{CH}), 98.4(\mathrm{CH}), 82.9(\mathrm{CH}), 77.7(\mathrm{CH}), 75.2\left(\mathrm{CH}_{2}\right)$, $75.0\left(\mathrm{CH}_{2}\right), 74.7(\mathrm{CH}), 73.5(\mathrm{CH}), 73.4\left(\mathrm{CH}_{2}\right), 72.5(\mathrm{CH}), 69.7$ and $69.5\left(\mathrm{CH}_{2}\right), 69.1(\mathrm{CH}), 68.9(\mathrm{CH}), 68.7\left(\mathrm{CH}_{2}\right), 67.1\left(\mathrm{CH}_{2}\right)$, $54.4(\mathrm{CH}), 50.4$ and $50.1\left(\mathrm{CH}_{2}\right), 47.1$ and $46.1\left(\mathrm{CH}_{2}\right), 29.7$ and $29.1\left(\mathrm{CH}_{2}\right), 27.8$ and $27.4\left(\mathrm{CH}_{2}\right), 23.5\left(\mathrm{CH}_{3}\right), 23.1\left(\mathrm{CH}_{2}\right), 19.9$ $\left(\mathrm{CH}_{3}\right), 16.4\left(\mathrm{CH}_{3}\right)$; LRMS-ESI $(m / z)$ : $1115.4\left[\mathrm{M}+\mathrm{Na}^{+}\right]$.

\section{L-Fucosamine disaccharide 19}

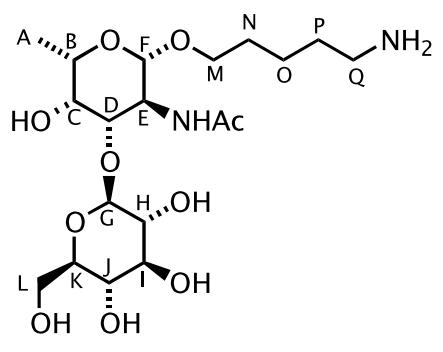

A solution of 18 (29 mg, $27.0 \mathrm{mmol}, 1.0$ equiv) in $\mathrm{MeOH}$ $(0.6 \mathrm{~mL})$ and THF $(0.6 \mathrm{~mL})$ was treated with $\mathrm{KOH}(0.8 \mathrm{mg}$, $13.5 \mathrm{mmol}, 0.5$ equiv) and stirred at $\mathrm{rt}$ for $30 \mathrm{~min} . \mathrm{H}_{2} \mathrm{O}(2 \mathrm{~mL})$ was added and the solvents were removed under vacuum. $\mathrm{CH}_{2} \mathrm{Cl}_{2}(5 \mathrm{~mL})$ was added and the layers were separated. The aqueous layer was extracted with $\mathrm{CH}_{2} \mathrm{Cl}_{2}(2 \times 5 \mathrm{~mL})$. The combined organic layers were dried $\left(\mathrm{MgSO}_{4}\right)$, filtered and concentrated. The crude product was solubilised in $\mathrm{MeOH} / \mathrm{H}_{2} \mathrm{O}$ / $\mathrm{AcOH}(3.0: 1.5: 0.06 \mathrm{~mL})$ and $\mathrm{Pd} / \mathrm{C}(30 \mathrm{mg})$ was added. The heterogeneous mixture was stirred under an atmosphere of $\mathrm{H}_{2}$ for $24 \mathrm{~h}$. The mixture was filtered over celite to give $\mathbf{1 9}(10 \mathrm{mg}$, $74 \%)$ as an amorphous solid; $[\alpha]_{\mathrm{D}}{ }^{20}+59.2\left(c 0.9, \mathrm{H}_{2} \mathrm{O}\right)$; ${ }^{1} \mathrm{H}$ NMR $\left(400 \mathrm{MHz}, \mathrm{D}_{2} \mathrm{O}\right) \delta 4.48\left(\mathrm{~d}, J=7.9 \mathrm{~Hz}, 1 \mathrm{H}, \mathrm{CH}^{\mathrm{G}}\right)$, $4.43\left(\mathrm{~d}, J=7.9 \mathrm{~Hz}, 1 \mathrm{H}, \mathrm{CH}^{\mathrm{F}}\right), 3.96-3.89\left(\mathrm{~m}, 3 \mathrm{H}, \mathrm{CH}^{\mathrm{C}}, \mathrm{CH}^{\mathrm{D}}\right.$ and $\left.\mathrm{CH}^{\mathrm{L}}\right), 3.88-3.80\left(\mathrm{~m}, 2 \mathrm{H}, \mathrm{CH}^{\mathrm{E}}\right.$ and $\left.\mathrm{CH}^{\mathrm{M}}\right), 3.72(\mathrm{q}, J=$ $\left.6.5 \mathrm{~Hz}, 1 \mathrm{H}, \mathrm{CH}^{\mathrm{B}}\right), 3.67\left(\mathrm{dd}, J=12.1,6.5 \mathrm{~Hz}, 1 \mathrm{H}, \mathrm{CH}^{\mathrm{L}}\right), 3.56$ $\left(\mathrm{dt}, J=10.2,6.2 \mathrm{~Hz}, 1 \mathrm{H}, \mathrm{CH}^{\mathrm{M}}\right), 3.45\left(\mathrm{t}, J=9.5 \mathrm{~Hz}, 1 \mathrm{H}, \mathrm{CH}^{\mathrm{I}}\right)$, $3.42-3.46\left(\mathrm{~m}, 1 \mathrm{H}, \mathrm{CH}^{\mathrm{J}}\right), 3.36-3.31\left(\mathrm{~m}, 1 \mathrm{H}, \mathrm{CH}^{\mathrm{K}}\right), 3.27(\mathrm{dd}, J=$ 9.5, 7.9 Hz, $\left.1 \mathrm{H}, \mathrm{CH}^{\mathrm{H}}\right), 2.95\left(\mathrm{t}, J=7.6 \mathrm{~Hz}, 2 \mathrm{H}, \mathrm{CH}_{2} \mathrm{Q}\right), 1.99(\mathrm{~s}$, $\left.3 \mathrm{H}, \mathrm{CH}_{3}\right), 1.97(\mathrm{~s}, 3 \mathrm{H}, \mathrm{AcOH}), 1.69-1.60\left(\mathrm{~m}, 2 \mathrm{H}, \mathrm{CH}_{2}{ }^{\mathrm{P}}\right)$, 1.59-1.50 (m, 2H, $\left.\mathrm{CH}_{2}{ }^{\mathrm{N}}\right), 1.42-1.32\left(\mathrm{~m}, 2 \mathrm{H}, \mathrm{CH}_{2}{ }^{\mathrm{O}}\right), 1.26(\mathrm{~d}, J$ $\left.=6.5 \mathrm{~Hz}, 3 \mathrm{H}, \mathrm{CH}_{3}{ }^{\mathrm{A}}\right) ;{ }^{13} \mathrm{C} \mathrm{NMR}\left(100 \mathrm{MHz}, \mathrm{D}_{2} \mathrm{O}\right) \delta 177.0$ $(\mathrm{C}=\mathrm{O}), 103.9\left(\mathrm{CH}^{\mathrm{F}}\right), 102.7\left(\mathrm{CH}^{\mathrm{G}}\right), 80.1\left(\mathrm{CH}^{\mathrm{D}}\right), 79.5\left(\mathrm{CH}^{\mathrm{I}}\right)$, 
$77.9\left(\mathrm{CH}^{\mathrm{J}}\right), 75.3\left(\mathrm{CH}^{\mathrm{B}}\right), 73.0\left(\mathrm{CH}^{\mathrm{H}}\right), 72.4\left(\mathrm{CH}_{2}^{\mathrm{L}}\right), 72.2\left(\mathrm{CH}^{\mathrm{K}}\right)$, $70.4\left(\mathrm{CH}^{\mathrm{C}}\right), 63.5\left(\mathrm{CH}_{2}{ }^{\mathrm{M}}\right), 52.8\left(\mathrm{CH}^{\mathrm{E}}\right), 41.7\left(\mathrm{CH}_{2}{ }^{\mathrm{Q}}\right), 30.5$ $\left(\mathrm{CH}_{2}{ }^{\mathrm{N}}\right), 28.8\left(\mathrm{CH}_{2}^{\mathrm{P}}\right), 24.8\left(\mathrm{CH}_{3}\right), 24.5\left(\mathrm{CH}_{2}{ }^{\mathrm{O}}\right), 24.4\left(\mathrm{CH}_{3}\right)$, $17.8\left(\mathrm{CH}_{3}\right)$; LRMS-ESI $(\mathrm{m} / \mathrm{z}): 453.2\left[\mathrm{M}+\mathrm{H}^{+}\right]$; HRMS-ESI $(\mathrm{m} /$ $z$ ): $\left[\mathrm{M}+\mathrm{H}^{+}\right]$calcd for $\mathrm{C}_{19} \mathrm{H}_{37} \mathrm{~N}_{2} \mathrm{O}_{10}, 453.244$; found, 453.2468 .

\section{Supporting Information}

\section{Supporting Information File 1}

${ }^{1} \mathrm{H}$ NMR, COSY, ${ }^{13} \mathrm{C}$ NMR and HSQC spectra and the crystallographic data file for D-8b.

[http://www.beilstein-journals.org/bjoc/content/ supplementary/1860-5397-9-38-S1.pdf]

\section{Acknowledgements}

The authors gratefully thank the Max Planck Society for generous funding, Dr. A. Hagelbach (FU) and Dr. A. Barandov (MPI) for X-ray crystallographic analyses, and Dr. I. Vilotjevic for helpful comments during the preparation of the manuscript.

\section{References}

1. Mariño, K.; Bones, J.; Kattla, J. J.; Rudd, P. M. Nat. Chem. Biol. 2010, 6, 713. doi:10.1038/nchembio.437

2. Arnold, J. N.; Wormald, M. R.; Sim, R. B.; Rudd, P. M.; Dwek, R. A. Annu. Rev. Immunol. 2007, 25, 21. doi:10.1146/annurev.immunol.25.022106.141702

3. Dube, D. H.; Bertozzi, C. R. Nat. Rev. Drug Discovery 2005, 4, 477. doi:10.1038/nrd1751

4. Stallforth, P.; Lepenies, B.; Adibekian, A.; Seeberger, P. H. J. Med. Chem. 2009, 52, 5561. doi:10.1021/jm900819p

5. Dube, D. H.; Champasa, K.; Wang, B. Chem. Commun. 2011, 47, 87. doi:10.1039/c0cc01557a

6. Boltje, T. J.; Buskas, T.; Boons, G.-J. Nat. Chem. 2009, 1, 611. doi:10.1038/nchem.399

7. Bieber, D.; Ramer, S. W.; Wu, C.-Y.; Murray, W. J.; Tobe, T.; Fernandez, R.; Schoolnik, G. K. Science 1998, 280, 2114. doi:10.1126/science.280.5372.2114

8. Banerjee, A.; Wang, R.; Supernavage, S. L.; Ghosh, S. K.; Parker, J.; Ganesh, N. F.; Wang, P. G.; Gulati, S.; Rice, P. A. J. Exp. Med. 2002, 196, 147. doi:10.1084/jem.20012022

9. Power, P. M.; Ku, S. C.; Rutter, K.; Warren, M. J.; Limnios, E. A.; Tapsall, J. W.; Jennings, M. P. Infect. Immun. 2007, 75, 3202. doi:10.1128/IAI.01501-06

10. Takeuchi, K.; Taguchi, F.; Inagaki, Y.; Toyoda, K.; Shiraishi, T.; Ichinose, Y. J. Bacteriol. 2003, 185, 6658 doi:10.1128/JB.185.22.6658-6665.2003

11. Horzempa, J.; Carlson, P. E., Jr.; O’Dee, D. M.; Shanks, R. M. Q.; Nau, G. J. BMC Microbiol. 2008, 8, No. 172. doi:10.1186/1471-2180-8-172

12. van Sorge, N. M.; Bleumink, N. M. C.; van Vliet, S. J.; Saeland, E.; van der Pol, W.-L.; van Kooyk, Y.; van Putten, J. P. M. Cell. Microbiol. 2009, 11, 1768. doi:10.1111/j.1462-5822.2009.01370.x

13. Verma, A.; Arora, S. K.; Kuravi, S. K.; Ramphal, R. Infect. Immun. 2005, 73, 8237. doi:10.1128/IAl.73.12.8237-8246.2005
14. Yang, Y.; Martin, C. E.; Seeberger, P. H. Chem. Sci. 2012, 3, 896. doi:10.1039/c1sc00804h

15. Martin, C. E.; Weishaupt, M. W.; Seeberger, P. H. Chem. Commun. 2011, 47, 10260. doi:10.1039/c1cc13614c

16. Ohara, T.; Adibekian, A.; Esposito, D.; Stallforth, P.; Seeberger, P. H. Chem. Commun. 2010, 46, 4106. doi:10.1039/c000784f

17. Smedley, J. G., III; Jewell, E.; Roguskie, J.; Horzempa, J.; Syboldt, A.; Stolz, D. B.; Castric, P. Infect. Immun. 2005, 73, 7922. doi:10.1128/IAI.73.12.7922-7931.2005

18. Castric, P.; Cassels, F. J.; Carlson, R. W. J. Biol. Chem. 2001, 276, 26479. doi:10.1074/jbc.M102685200

19. Chamot-Rooke, J.; Rousseau, B.; Lanternier, F.; Mikaty, G.; Mairey, E.; Malosse, C.; Bouchoux, G.; Pelicic, V.; Camoin, L.; Nassif, X.; Duménil, G. Proc. Natl. Acad. Sci. U. S. A. 2007, 104, 14783. doi:10.1073/pnas.0705335104

20. Kus, J. V.; Kelly, J.; Tessier, L.; Harvey, H.; Cvitkovitch, D. G.; Burrows, L. L. J. Bacteriol. 2008, 190, 7464. doi:10.1128/JB.01075-08

21. Castric, P. Microbiology (Reading, U. K.) 1995, 141, 1247. doi:10.1099/13500872-141-5-1247

22. Sugawara, K.; Tsunakawa, M.; Konishi, M.; Kawaguchi, J.; Krishnan, B.; He, C. H.; Clardy, J. J. Org. Chem. 1987, 52, 996. doi:10.1021/jo00382a005

23. Myers, A. G.; Liang, J.; Hammond, M.; Harrington, P. M.; Wu, Y.; Kuo, E. Y. J. Am. Chem. Soc. 1998, 120, 5319. doi:10.1021/ja980588y

24. Zhu, X.; Schmidt, R. R. Angew. Chem., Int. Ed. 2009, 48, 1900. doi:10.1002/anie.200802036

25. Bongat, A. F. G.; Demchenko, A. V. Carbohydr. Res. 2007, 342, 374. doi:10.1016/j.carres.2006.10.021

26. Buskas, T.; Ingale, S.; Boons, G.-J. Glycobiology 2006, 16, $113 R$. doi:10.1093/glycob/cwj125

27. Codée, J. D. C.; Litjens, R. E. J. N.; van den Bos, L. J.; Overkleeft, H. S.; van der Marel, G. A. Chem. Soc. Rev. 2005, 34, 769 doi:10.1039/b417138c

28. Boons, G.-J.; Demchenko, A. V. Chem. Rev. 2000, 100, 4539. doi:10.1021/cr990313g

29. Liav, A.; Hildesheim, J.; Zehavi, U.; Sharon, N. Carbohydr. Res. 1974, 33, 217. doi:10.1016/S0008-6215(00)82799-8

30. Busca, P.; Martin, O. R. Tetrahedron Lett. 2004, 45, 4433. doi:10.1016/j.tetlet.2004.04.074

31. Jones, G. B.; Lin, Y.; Xiao, Z.; Kappen, L.; Goldberg, I. H. Bioorg. Med. Chem. 2007, 15, 784. doi:10.1016/j.bmc.2006.10.052

32. Weerapana, E.; Glover, K. J.; Chen, M. M.; Imperiali, B. J. Am. Chem. Soc. 2005, 127, 13766. doi:10.1021/ja054265v

33. Amin, M. N.; Ishiwata, A.; Ito, Y. Carbohydr. Res. 2006, 341, 1922. doi:10.1016/j.carres.2006.04.031

34. Schmidt, R. R. Pure Appl. Chem. 1987, 59, 415 doi:10.1351/pac198759030415

35. Kirschning, A.; Jesberger, M.; Schöning, K.-U. Synthesis 2001, 507. doi:10.1055/s-2001-12342

36. Hemeon, I.; Bennet, A. J. Synthesis 2007, 1899. doi:10.1055/s-2007-983723

37. Vogel, P. In The Organic Chemistry of Sugars; Levy, D. E.; Fugedi, P., Eds.; Taylor and Francis Group/CRC Press: Boca Raton, FL, 2006; pp $629 \mathrm{ff}$.

38. Voigt, B.; Scheffler, U.; Mahrwald, R. Chem. Commun. 2012, 48, 5304. doi:10.1039/c2cc31541f

39. Crich, D.; Navuluri, C. Org. Lett. 2011, 13, 6288. doi:10.1021/ol202773t

40. Lorpitthaya, R.; Suryawanshi, S. B.; Wang, S.; Pasunooti, K. K.; Cai, S.; Ma, J.; Liu, X.-W. Angew. Chem., Int. Ed. 2011, 50, 12054. doi:10.1002/anie.201104516 
41. Northrup, A. B.; MacMillan, D. W. C. Science 2004, 305, 1752. doi:10.1126/science.1101710

42. Babu, R. S.; Zhou, M.; O'Doherty, G. A. J. Am. Chem. Soc. 2004, 126, 3428. doi:10.1021/ja039400n

43. Enders, D.; Grondal, C. Angew. Chem., Int. Ed. 2005, 44, 1210. doi:10.1002/anie.200462428

44. Calin, O.; Pragani, R.; Seeberger, P. H. J. Org. Chem. 2012, 77, 870. doi:10.1021/jo201883k

45. Pragani, R.; Seeberger, P. H. J. Am. Chem. Soc. 2011, 133, 102. doi:10.1021/ja1087375

46. Pragani, R.; Stallforth, P.; Seeberger, P. H. Org. Lett. 2010, 12, 1624. doi:10.1021/ol1003912

47. Leonori, D.; Seeberger, P. H. Org. Lett. 2012, 14, 4954. doi:10.1021/ol3023227

48. Garner, P. Tetrahedron Lett. 1984, 25, 5855. doi:10.1016/S0040-4039(01)81703-2

49. Cram, D. J.; Kopecky, K. R. J. Am. Chem. Soc. 1959, 81, 2748. doi:10.1021/ja01520a036

50. O'Brien, A. G. Tetrahedron 2011, 67, 9639. doi:10.1016/j.tet.2011.10.002

51. Zhang, X.; van der Donk, W. A. J. Am. Chem. Soc. 2007, 129, 2212. doi:10.1021/ja067672v

52. Garner, P.; Park, J. M.; Malecki, E. J. Org. Chem. 1988, 53, 4395. doi:10.1021/jo00253a039

53. Blot, V.; Jacquemard, U.; Reissig, H.-U.; Kleuser, B. Synthesis 2009, 759. doi:10.1055/s-0028-1083373

54. Trost, B. M.; Ball, Z. T.; Jöge, T. J. Am. Chem. Soc. 2002, 124, 7922. doi:10.1021/ja026457।

55. Trost, B. M.; Ball, Z. T. J. Am. Chem. Soc. 2005, 127, 17644 doi:10.1021/ja0528580

56. Dess, D. B.; Martin, J. C. J. Org. Chem. 1983, 48, 4155. doi:10.1021/j000170a070

57. Gaunt, M. J.; Yu, J.; Spencer, J. B. J. Org. Chem. 1998, 63, 4172. doi:10.1021/jo980823v

58. Liao, W.; Locke, R. D.; Matta, K. L. Chem. Commun. 2000, 369. doi:10.1039/a908511d

59. Lipták, A.; Borbás, A.; Jánossy, L.; Szilágyi, L. Tetrahedron Lett. 2000, 41, 4949. doi:10.1016/S0040-4039(00)00735-8

60. Cha, J. K.; Kim, N.-S. Chem. Rev. 1995, 95, 1761. doi:10.1021/cr00038a003

61. Cha, J. K.; Christ, W. J.; Kishi, Y. Tetrahedron Lett. 1983, 24, 3943. doi:10.1016/S0040-4039(00)88231-3

62. Karjalainen, O. K.; Koskinen, A. M. P. Org. Biomol. Chem. 2011, 9, 1231. doi:10.1039/c0ob00747a

63. Mancuso, A. J.; Swern, D. Synthesis 1981, 165. doi:10.1055/s-1981-29377

64. Dondoni, A.; Perrone, D. Org. Synth. 2004, Coll. Vol. 10, 320.

65. Parikh, J. R.; Doering, W. v. E. J. Am. Chem. Soc. 1967, 89, 5505. doi:10.1021/ja00997a067

66. De Luca, L.; Giacomelli, G.; Masala, S.; Porcheddu, A. J. Org. Chem. 2003, 68, 4999. doi:10.1021/jo034276b

67. Snapper, C. M.; Mond, J. J. J. Immunol. 1996, 157, 2229.

68. Plé, K.; Chwalek, M.; Voutquenne-Nazabadioko, L. Tetrahedron 2005, 61, 4347. doi:10.1016/j.tet.2005.03.003

\section{License and Terms}

This is an Open Access article under the terms of the Creative Commons Attribution License

(http://creativecommons.org/licenses/by/2.0), which permits unrestricted use, distribution, and reproduction in any medium, provided the original work is properly cited.

The license is subject to the Beilstein Journal of Organic Chemistry terms and conditions:

(http://www.beilstein-journals.org/bjoc)

The definitive version of this article is the electronic one which can be found at: doi:10.3762/bjoc.9.38 